\title{
Korean potential approach to the multi-lateralization of the nuclear fuel cycle
}

\author{
Joo Hyun Moon \\ Dongguk University, Gyeongju, South Korea; jhmoon86@dongguk.ac.kr
}

Received 11 September 2012; revised 16 October 2012; accepted 27 October 2012

\begin{abstract}
To prevent the worldwide dissemination of nuclear sensitive technologies and strengthen the safeguards of the nuclear facilities at the same time, the international society has begun to discuss the "multilateral nuclear fuel cycle approach (MNA)". This kind of discussion will be more vigorous due to the recent nuclear activeties in Iran and North Korean and the Fukushima nuclear power plants accidents. If the MNA would be implemented someday, not even in the immediate future, Korea could be subject to a serious situation since it imports $100 \%$ of raw material for nuclear fuel. Hence, this paper reviews the 12 previous MNA proposals and discusses a potential Korean approach to MNA that Korea is able to take.
\end{abstract}

Keywords: Nuclear Sensitive Technologies; Safeguards; Nuclear Facilities; Multilateral Nuclear Fuel Cycle Approach

\section{INTRODUCTION}

Recent nuclear activities in Iran and North Korea require a re-evaluation of increasing nuclear fuel supplies to specific nations versus strengthened security for all countries against the use of weapons of mass destruction (WMD). Also, the accidents at Fukushima Diichi nuclear power plants on 11 March 2011 have also raised the security of nuclear power as one of the most important issues about the future of nuclear power. Even though it was caused by a natural disaster such as an earthquake followed by a tsunami, the Fukushima event prefigured the risk that a state or a non-state actor may select a nuclear fuel cycle facility, especially reactors and spent fuel ponds, as targets for radiological warfare [1]. The Fukushima accident implicitly shows the overlap between nuclear safety and nuclear security concerns.

To prevent the worldwide dissemination of sensitive technologies and strengthen the safeguard of the nuclear facilities at the same time, the international society has made efforts to develop an institutional system of a multilateral approach to the nuclear fuel cycle to complement the technical measures that alone could not compensate for the limitations of the existing nuclear nonproliferation regime.

Since 2003, 12 proposals have been put forward by states, nuclear industry and international organizations, which aim to check the spread of uranium enrichment and spent nuclear fuel reprocessing technologies, in particular by suggesting a means of assuring nuclear fuel supplies and establishing international fuel cycle centers [2]. In general, different countries have tried to implement the concept of the multilateral nuclear fuel cycle as follows: Proposal on a reserve of nuclear fuel (USA) [3], global nuclear power infrastructure (Russia) [4], global nuclear energy partnership (USA) [5], World Nuclear Association proposal [6], six-country concept (France, Germany, Netherlands, Russia, UK, Northern Ireland and USA) [7], IAEA standby arrangement (Japan) [8], nuclear threat initiative fuel bank (Nuclear Threat Initiative) [9], enrichment bonds (UK) [10], international uranium enrichment center (Russia) [11], multilateral enrichment sanctuary project (Germany) [12-14], multilateralization of the nuclear fuel cycle (Austria) [15] and a non-paper on the nuclear fuel cycle (EU) [16].

There has been a clear sign for an international society to begin discussions of "multilateral nuclear fuel cycle approach (MNA)” when the Iranian nuclear development became an international hot issue. This kind of discussion will be more vigorous due to the Fukushima accident. Though most proposals were just at conceptual phase since there are several barriers of technique and institution to arrive at the implementation phase of them, it cannot be excluded the possibility for a concrete and executable MNA to be emerged in near future since the countries of advanced nuclear-technology are willingly trying to lead the international discussion of the MNA.

If the MNA would be implemented someday, not even in the immediate future, Korea could be subject to a serious situation since it imports $100 \%$ of raw material for nuclear fuel. Also, the export of nuclear power plant 
would be impacted either in positive or in negative way. Hence, it is necessary to follow and take active participation in the international discussions of MNA. In this context, this paper reviews the 12 previous MNA proposals and discusses a potential Korean approach to MNA that Korea is able to take.

\section{REVIEW OF THE 12 MNA PROPOSALS}

The 12 MNA proposals that are in the Table $\mathbf{1}$ differ considerably in their vision, scope, targets and time required for their implementation. Most proposals are rather limited in their goals, dealing primarily with the front end of the nuclear fuel cycle, that is, the supply of nuclear fuel and, in particular, LEU for power production. The proposals can be categorized into three groups according to the mechanism of securing nuclear fuel supply [2]:

- Providing backup assurances of supply in addition to the existing commercial uranium market (WNA proposal, Six-Country Concept, Japanese IAEA Standby Arrangements, UK Enrichment Bonds);

- Establishing nationally controlled (US reserve of nuclear fuel, WNA proposal, Six-Country Concept) or IAEA-controlled LEU reserves (Russian IUEC, NTI Fuel Bank) as a last resort in the event the existing market for nuclear fuel fails;

- Establishing/placing uranium enrichment facilities under some form of international control, including the establishment of an IAEA controlled uranium enrichment facility (Russian IUEC, German MESP proposal).
The 12 proposals have aimed at the common goal of securing energy supply and strengthening non-proliferation regime, but have been not welcomed by most countries since they have the two critical limitations:

First, most of the 12 previous proposals divided the nations of the world into two categories, i.e., nuclear fuel cycle service supplier country and consumer country, then, emphasized the nonproliferation logics from supplier countries' stance. These proposals were meaningful in preventing the dissemination of nuclear sensitive technologies and promoting the peaceful utilization of nuclear energy, but intended to restrict the right for peaceful use of nuclear energy - even though it is sensitive technology, which is guaranteed by article 3 in the Nonproliferation Treaty, and to block any access of non-nuclear weapon state, strictly speaking, nuclear fuel cycle service consumer nation to the nuclear sensitive technologies. Hence, if it becomes in effect, the MNA regime could be acted as a barrier to nuclear sensitive technologies and then transformed into a discriminatory regime to divide the nations of the world into the supply or consumer county and set this categorization in. Due to these facts, while the countries that hold the enrichment and/or reprocessing facilities support the MNA, the other countries that don't hold them oppose or are negative on it.

Second, all the twelve proposals didn't suggest the sufficient compensations for forgoing the nuclear sensitive technologies. As described above, most of the twelve proposals suggested just securing supply of uranium enrichment service as a reward for forging the nuclear sensitive technologies, for which most consumer countries are unsatisfied with. That is why the world market of

Table 1. Comparison of existing proposals by timeframe and scope [2].

\begin{tabular}{|c|c|c|}
\hline Time frame & Proposal & Scope \\
\hline \multirow{4}{*}{ Short term } & Russian IUEC & $\begin{array}{l}\text { Establishment of an IUEC under the IAEA safeguards; establishment of an } \\
\text { IAEA-controlled LEU reserve }\end{array}$ \\
\hline & US Reserve of Nuclear Fuel & Establishment of a nationally controlled LEU reserve \\
\hline & $\begin{array}{l}\text { Combination of Six-Country Concept and } \\
\text { WNA proposal, supplemented by } \\
\text { Enrichment Bonds and IAEA Standby } \\
\text { Arrangements }\end{array}$ & $\begin{array}{l}\text { Backup assurances of LEU and nuclear fuel supply in addition to the existing } \\
\text { commercial uranium market; establishment of nationally controlled reserve }\end{array}$ \\
\hline & NTI Fuel Bank & Establishment of an IAEA-controlled LEU reserve \\
\hline \multirow[t]{2}{*}{ Mid-term } & German MESP Proposal & $\begin{array}{l}\text { Establishment of an IAEA-controlled international uranium enrichment plant in an } \\
\text { extraterritorial area }\end{array}$ \\
\hline & $\begin{array}{l}\text { Russian Global Nuclear Power } \\
\text { Infrastructure }\end{array}$ & $\begin{array}{l}\text { Establishment of a global supply mechanism. A system of international centers } \\
\text { providing fuel cycle services from uranium enrichment and fuel supply to spent } \\
\text { fuel take-back and reprocessing }\end{array}$ \\
\hline \multirow[t]{2}{*}{ Long term } & US Global Nuclear Energy Partnership & $\begin{array}{l}\text { Establishment of a global supply mechanism. Front-end and back-end services } \\
\text { provided by a limited number of supplier states using new proliferation-resistant } \\
\text { technologies }\end{array}$ \\
\hline & $\begin{array}{l}\text { Multilateralization of the Nuclear Fuel } \\
\text { Cycle }\end{array}$ & $\begin{array}{l}\text { Establishment of a mechanism directed on eventual placing of the existing civilian } \\
\text { enrichment and reprocessing facilities and fuel supply activities under multilateral } \\
\text { control }\end{array}$ \\
\hline
\end{tabular}


uranium and enrichment service has been reliably operated without any uranium supply failure. At present, hence, consumer countries don't have any problem securing uranium and enrichment services in the existing market, and feel no necessity to accept the MNA regime at the cost of forgoing the nuclear sensitive technologies. In order to implement the MNA regime, hence, it is essential that another attractive incentive corresponding to abandonment of the nuclear sensitive technologies be suggested or the privileges that the supply countries have enjoyed be given up.

\section{CURRENT STATUS AND POTENTIAL IMPACTS ON KOREA}

\subsection{Current Status of Korea}

The Korean government has maintained a consistent national policy for stable energy supply by fostering nuclear power industries under the insufficient energy resources in the country. Nuclear power reached approximately $40 \%$ of total domestic electricity generation.

Since the commencement of the first commercial operation of Kori Unit 1 in April 1978, 23 units of nuclear power plants (NPPs) are commercially operating as of September 2012. Four units out of the 23 operating NPPs are Pressurized Heavy Water Reactors (PHWRs) at Wolsong. The 19 units located in Kori, Wolsung, Yonggwang, and Ulchin are Pressurized Light Water Reactors (PWRs). There are 4 units (OPR1000 1 units, APR1400 3 units) under construction. Also, a group of KEPCO-led Korean companies was selected as the final bidder for an order to build four units of NPPs placed by the United Arab Emirate in 2009.

\subsection{Potential Impacts of MNA on Korea}

Though it is not expected that the MNA regime will be implemented in the immediate future, it could have a large impact on Korea if it is implemented. First, the level of foreign dependency of energy security will be gotten higher. At present, Korea imports $100 \%$ of nuclear raw material from foreign countries, but diversify the risk of supply failure through diversification of contractors and contract terms. If the Korea is entered into the regime of MNA as a consumer country, however, Korea wholly relies on the supply cartel consisting of a few uranium suppliers for uranium and uranium enrichment service. Then, from the long-term viewpoint, Korea is likely to be placed in an unfavorable situation. At the early implementation stage of MNA regime, it is highly possible to supply the uranium and enrichment service at cost equivalent to or lower than market price in order to attract voluntary participation from nations as many as possible. Once the MNA regime is stabilized and oli- gopolistic market of uranium and enrichment service is formed, it cannot be rashly anticipated that such price policy will be kept for a long time.

If Korea is entered as a supplier country, the Korea could get an access to uranium enrichment technologies or have its own enrichment facilities. However, it is very unlikely for this situation to occur since the Korea has no infrastructure and technologies related to uranium mining and enrichment, but just hold a nuclear fuel fabrication facility at present. In case, the Korea could be just a nuclear fuel fabricator.

Second, the export competitiveness of Korean nuclear power plant could be impacted. Upon exporting nuclear power plant, nuclear fuel supply should be guaranteed to an importing country. Once the MNA regime is implemented and Korea is entered into it as a consumer country, Korea would be placed in worse condition than other export countries such as US, Russia, and France that can provide the nuclear fuel services independently because the importing countries are likely to prefer terms of contract to provide nuclear plant as well as the nuclear fuel cycle services such as nuclear fuel supply and spent nuclear fuel management. Even if Korea can export a nuclear power plant, Korea cannot supply nuclear fuel to the importing country and cannot expect additional profits resulting from supplying the nuclear fuel after export of nuclear power plant. These facts would seriously undermine the export competitiveness and profit structure of Korean nuclear power plant. However, if Korea is entered as a supplier country, Korea could quietly increase its export competitiveness since it can propose a variety of nuclear fuel supply options to an importing country.

Third, the national policy to expand nuclear energy could be impacted. Since there are institutional and technical problems to be solved regarding the process and disposal spent nuclear fuel, the existing MNA proposals dare not to propose for the back-end fuel cycle services. If Korea forgoes the development of spent nuclear fuel recycling technology after entering into MNA regime as a consumer country, the disposal of increasing spent nuclear fuel will become a big issue since it cannot manage the spent nuclear fuel according to its own will. Since the MNA regime is not a complete regime to provide the total services for the back-end nuclear fuel cycle, the national policy of expanding nuclear energy for securing national energy security and reducing green gas emission will reach an impasse.

\section{POTENTIAL KOREAN APPROACH TO MNA}

As discussed in the previous section, if it is entered into MNA regime as a consumer country, Korean nuclear 
industry would be in a serious situation. But if it is entered as a supplier country, Korea will have several advantages in promoting the domestic nuclear industry and exporting nuclear power plants. Hence, Korea has to actively correspond to the present situation where the discussion of MAN has been led by the advanced countries like German and France. For this, hence, it is necessary to make the international discussion framework of MNA favorable to Korea, for example, by suggesting our own MNA proposal for which the Korea is able to take the initiative.

The review results show that the rights for peaceful use of nuclear energy and the voluntary choice of the non-nuclear weapon states shall be guaranteed in order to minimize the hatred of the non-nuclear weapon states to the MNA that may constrain them. Hence, the Korea has to approach to MNA based on the following basic principles in order to be acceptable to as many countries as possible and to be more favorable to Korea.

- Besides strengthening the international nonproliferation regime, the rights of non-nuclear weapon states for peaceful use of nuclear energy, which are stipulated in article 4 of the non-proliferation treaty, and their voluntary choices shall be guaranteed.

- The base of "the expansion of peaceful use of nuclear energy" that Korean government has made clear shall be strengthened.

Under the basic principles, the potential Korean approach could be formulated as follows:

Step 1: Maximization of international nuclear transparency. All the countries shall declare their all current nuclear programs and future nuclear program plan to each other and IAEA.

Step 2: Guarantee of the right of voluntary choice. According to the country's own choice, IAEA, together with the party country, jointly develop the front- and back-end nuclear fuel cycle service program suitable for the nation, and keeps monitoring whether the country implements the programs appropriately. The supply of front- and back-end nuclear fuel services to the countries who forgo nuclear sensitive technologies and facilities shall be guaranteed.

Step 3: Guarantee of the impartial access to the nuclear sensitive technologies. For the nation for which IAEA judged it indispensable to develop its own nuclear sensitive technologies and facilities, the nation will designate a certain area as "a sanctuary area" and transfer the jurisdiction of the area to IAEA, where, under the auspice of IAEA, the multilateral facilities for development and commercialization of nuclear sensitive technologies necessary for the nation will be constructed and operated. In the construction and operation, the 3rd countries, including the country directly concerned, could be participated.

\section{DISCUSSION}

There has been a clear sign for an international society to begin discussions of MNA when the Iranian nuclear development became an international hot issue. This kind of discussion will be more vigorous by the Fukushima accident. If it is entered into MNA regime as a consumer country, Korean nuclear industry would be in a serious situation. But if it is entered as a supplier country, Korea will have several advantages in promoting the domestic nuclear industry and exporting nuclear power plants. Hence, it is necessary to follow and take active participation in the international discussions of MNA. In this context, this paper reviews the 12 previous MNA proposals and discusses a potential Korean approach to MNA that Korea is able to take.

The Korean potential approach is based on the two principles to guarantee the rights of non-nuclear weapon states for peaceful use of nuclear energy and strengthen the base of "the expansion of peaceful use of nuclear energy", and consists of the three steps as described in Section 4. The Korean potential approach is expected to apply to solve the various nuclear problems. For domestic case, the Korean potential approach can be applied to develop spent nuclear fuel recycling technologies and facilities. For the Iran's and the North's nuclear problems, the multilateral approach would be quite helpful for their complete denuclearization by redirecting the Iran's and the North's nuclear workers and ruling out the possibility of restarting the nuclear weapon program. In addition, it will be very helpful to prevent the dissemination of sensitive nuclear technologies, particularly in Far East Asia by guaranteeing to provide uranium enrichment and spent fuel reprocessing services at reasonable prices to the countries requesting them, which is the main purpose of the multilateral approach to the nuclear fuel cycle.

\section{REFERENCES}

[1] Dalton, T. (2011) Nuclear security after Fukushima. http://carnegieendowment.org/2011/04/13/nuclear-securit y-after-fukushima/5ft

[2] Yudin, Y. (2009) Multilateralization of the nuclear fuel cycle: Assessing the existing proposals. United Nations Institute for Disarmament Research, Geneva.

[3] IAEA (2005) Communication dated 28 September 2005 from the permanent mission of the United States of America to the agency. International Atomic Energy Agency, Wien.

[4] IAEA (2006) Communication received from the resident representative of the Russian federation to the agency transmitting the text of the statement of the president of the Russian federation on the peaceful use of nuclear energy. International Atomic Energy Agency, Wien.

[5] US DOE (2006) Global nuclear energy partnership: Greater 
energy security in a cleaner, safer world. US Department of Energy, Washington DC.

http://energy.gov/sites/prod/files/.../06-GA50035b.pdf

[6] WNA (2006) Ensuring security of supply in the international nuclear fuel cycle. World Nuclear Association, Westminster.

http://www.world-nuclear.org/reference/pdf/security.pdf

[7] IAEA (2006) Communication dated 31 May 2006 received from the permanent missions of France, Germany, the Netherlands, the Russian Federation, the United Kingdom of Great Britain and Northern Ireland and the United States of America. International Atomic Energy Agency, Wien.

[8] IAEA (2006) Communication received on 12 September 2006 from the permanent mission of Japan to the agency concerning arrangements for the assurance of nuclear fuel supply. International Atomic Energy Agency, Wien.

[9] NTI (2006) Nuclear threat initiative commits \$50 million to create IAEA Nuclear Fuel Bank. Nuclear Threat Initiative Press.

http://www.nti.org/newsroom/news/nti-commits-50-milli on-iaea-nuclear-fuel-bank

[10] IAEA (2007) Communication dated 30 May 2007 from the permanent mission of the United Kingdom of Great Britain and Northern Ireland to the IAEA concerning enrichment bonds-A voluntary scheme for reliable access to nuclear fuel. International Atomic Energy Agency, Wien.
[11] IAEA (2007) Communication received from the resident representative of the Russian federation to the IAEA on the establishment, structure and operation of the International Uranium Enrichment Centre. International Atomic Energy Agency, Wien.

[12] IAEA (2007) Communication received from the resident representative of Germany to the IAEA with regard to the German proposal on the multilateralization of the Nuclear Fuel Cycle. International Atomic Energy Agency, Wien.

[13] IAEA (2008) Communication dated 30 May 2008 received from the permanent mission of the Federal Republic of Germany to the agency with regard to the German proposal for a multilateral enrichment sanctuary project. International Atomic Energy Agency, Wien.

[14] IAEA (2008) Communication dated 22 September 2008 received from the permanent mission of Germany to the agency regarding the German proposal on a multilateral enrichment sanctuary project. International Atomic Energy Agency, Wien.

[15] IAEA (2007) Communication received from the federal minister for European and international affairs of Austria with regard to the Austrian proposal on the multilateralization of the nuclear fuel cycle. International Atomic Energy Agency, Wien.

[16] EU (2008) Nuclear fuel cycle, non-paper circulated in Vienna. European Union, Brussels. 